\title{
Aquaphobia, Tulipmania, Biophilia: A Moral Geography of the Dutch Landscape
}

\author{
HUB ZWART
}

University of Nijmegen

Dept. of Philosophy and Science Studies

PO Box 9010, 6500 GL Nijmegen, The Netherlands

E-mail:Haezwart@sci.kun.nl

\begin{abstract}
In Genesis (1:9-10) we are told that God gathered the waters into one place, in order to let the dry land appear, which He called earth, while the waters were called seas. In the Netherlands, this process took more than a single day, and it was the work of man. Gradually, a cultivated landscape emerged out of diffuse nature. In the course of centuries, the Dutch determined the conditions that allowed different aspects of nature to present themselves. This process is described as a moral geography in the sense that different types of landscape are read as a manifestations (or materialisations) of different moral attitudes towards nature, whereas concrete landscape interventions are interpreted as instances of moral criticism directed towards the activities and values of previous generations. At present, this process (the genesis of the Dutch landscape) is being reversed, as diffuse, wetland nature is experiencing a come-back.
\end{abstract}

\section{KEY WORDS}

Environmental history, philosophy of landscape, basic attitudes towards nature, wetland rehabilitation

\section{INTRODUCTION}

According to the famous geographer and naturalist Alexander von Humboldt (1808/1975), nature first of all manifests itself in landscapes. All landscapes convey a sense of nature as such, but they all do so in their own particular manner. In his book Ansichten der Natur (Views of Nature) he points out that every landscape has a distinctive character of its own. A peculiar 'physiognomy' 


\section{HUB ZWART}

belongs to every region on earth, from the polar to the tropical zone. It impresses the visitor in a certain manner, conveys a certain Totaleindruck, calls forth a certain basic mood. According to Von Humboldt, the physiognomy of a landscape is determined by climatological and geographical features of the area involved, but attaches itself to a typical plant form that gives the landscape at hand its identity, its face. The palm form, the banana form, the cactus form and the grass form are among Von Humboldt's examples. In fact, sixteen different landscapes or regional types, associated with (and represented by) typical plant forms are distinguished, but Von Humboldt points out that other forms may be added to the list.

Von Humboldt's idea is a product of the Romantic era and we way wonder to what extent it still applies to our present world. Although we still inhabit landscapes, many of them are (or have been) subject to drastic modifications. My own landscape, that of the Netherlands, may stand as an example. It is not one landscape, but rather an amalgam of landscape fragments that emerged during different historical periods - all of them more or less man-made. Following Von Humboldt's suggestion it is possible to explain how they evolved within certain geographical and climatological constraints and came to be associated with certain typical plant forms. But whereas Von Humboldt preferably studied landscapes in their pristine state, unspoiled by human influence, the Dutch landscape must be studied from an historical perspective that includes the effects of human activity. The landscape of the Netherlands is the outcome of a long history - a moral history in fact, because the physiognomies of man-made landscapes reflect the moral attitudes of its creators towards nature. Indeed, the basic idea behind this article is that landscape types may be read as materialisations of the moral ideas and values that guided their creation. I will regard the Dutch landscape as the outcome of a series of dramatic interactions between man and nature. A 'moral geography' of a landscape will interpret anthropogenic modifications as forms of moral criticism directed towards the values, choices and achievements of previous generations. In this article, I will focus on a limited number of highlights or dramatic shifts that gave the Dutch landscape its present appearance. Notably, I will reflect on the transitions that occurred during the early modern period and gave birth to the two most outstanding and enduring icons of the Dutch landscape: the windmill and the tulip. Finally, I will indicate how some of the remarkable landscape modifications that are taking place at this very moment seem to invert the changes that were brought about during the early modern period (or 'classical age').

The history of the Dutch landscape is first of all a prehuman, elementary history. Glaciers shaped its geological matrix, glacial winds and wandering rivers left their deposits, and sea-level fluctuations determined its coast line. But the most significant 'element' that effectively shaped the Dutch landscape was neither wind nor water, but man as a species. We seem to be without a habitat of our own. We create our habitat and for that reason we seem to be able to live 
almost anywhere, from the polar to the tropical regions - even in the Netherlands, a densely populated area sixty percent of which is actually situated below sea level. According to strict geological determinism, one would expect to find there nothing but a fever-ridden delta and lagoons, sluggish streams and stagnant or brackish waters, the undisputed domain of sea fowl and migratory birds, but not a very hospitable place for humans (Wagret 1968, p. vi). The Dutch landscape had to be created by its inhabitants and in this article I will indicate how its physiognomy reflects their basic moral attitudes and how these attitudes can be associated with a number of typical plant forms, serving as basic markers for a moral geography.

\section{AN ELEMENTARY HISTORY}

The geographical backdrop of the Dutch landscape is the elementary struggle between land, wind and water. Geographically speaking, the western and northern (or Holocene) parts of the Netherlands are slowly subsiding. The lateral moraine that once transected the area from east to west is still clearly visible in the east (near Nijmegen), where it forms a series of steep hills, but they gradually diminish in size towards the west and by the time Amsterdam is reached the sandy peaks have already disappeared fifteen metres below sea-level. Until recently, this process of subsidence was counteracted by periodical floodings, covering the area with substantial deposits. Since the Middle Ages, however, anthropogenic factors have undermined this balance of power. In the absence of intensive water management, the greater part of what is now called the Netherlands would be flooded and lost to the sea.

About 23 centuries ago, the post-glacial rise of sea-level halted more or less and the present Dutch coast line emerged. It basically consisted of sand dunes, with extended mud-flats and tidal salt-marsh areas (exposed to the sea by tidal inlets) right behind them, and intersected by the branches and estuaries of the Rhine, Meuse and Scheldt. Pliny (1945/1960) informs us that in Roman times, the northern and western parts of the country were regularly flooded. In some areas the sea was allowed to enter twice a day. In the eyes of Roman visitors, it was difficult to tell whether this bleak, appalling, boundless, treeless landscape of coastal marshes, alternately flooded and exposed by the tides, should be called land or sea. Forest vegetation was nowhere to be found (p. 387/389). Pliny also noticed that the pitiful inhabitants sought their retreat on small artificial hummocks of earth (the famous terps), where they warmed their limbs, numbed by the shivering north wind, at peat fires. The policy of building terps lasted until the eleventh century A.D. It constituted a passive form of sea defence. The terp materialised a moral attitude of Gelassenheit so to speak. The inhabitants, whose deities were actually weather gods, simply waited until the overwhelming, demonic forces of nature retreated of their own accord. Nature simply was 


\section{HUB ZWART}

beyond human control. Primal nature - physis - was still part of daily life and experience.

Around the year 800 A.D., the landscape of the Netherlands had hardly been influenced by man. In the centuries to come, however, human inhabitants became the decisive factor in the formation and deformation of the land (Van de Ven 1993, p. 33; IDG-Bulletin 1996). Slowly but unrelentingly a major transition occurred. Building terps gradually gave way to a more active form of water management. The Dutch started to dig ditches and to construct small dikes. From around 800 A.D. they began to drain the vast peat-bogs to open them up for cultivation. Large peat areas were reclaimed and as a result, these lowlands became more vulnerable to flooding, by sea- as well as by river water. Man was not only a disturbing, but also a consolidating factor, however, notably by building dikes: a new and more active form of water management. The first dikes were erected during the eight century A.D. and the two forms of water management, terp-building and dike-building, coexisted for quite some time. Eventually, however, the new, more active regime was to have dramatic ecological consequences. Between the late tenth and the early fourteenth century, Tebrake (1985) tells us, the face of the Dutch landscape was drastically transformed. A wide expanse of wilderness, with small scattered patches of settlement and agricultural activity, was changed into a more or less continuous agrarian landscape. The greater part of the Netherlands was brought into the world of human affairs during that period. Huge quantities of previously unused lands were incorporated into the realm of culture. In the former peat-bog wilderness villages were founded and farms were built on parcels of standardised size and shape. The reclamation, by means of dikes and ditches, of formerly remote, impassable, soggy and swampy areas, where the imprint of human presence had been absent or slight, irrevocably altered the physical appearance of the Netherlands. The landscape was thoroughly humanised. Until this time, human presence had merely produced patches of dry, arable land within a matrix of humid wilderness. But after 1000 A.D., a geometrisation of the landscape took place at an increasing pace and the natural matrix was increasingly fragmented until only a few marginal leftovers remained. Gradually, through diligent manual labour by generations of anonymous farmers, a diffuse, ambiguous, soggy and brackish landscape, in which clear boundaries between land and water (as well as between fresh and saline water) were absent, was replaced by a discrete, highly compartmentalised landscape. For indeed, whereas vague and gradual transitions are characteristic of natural landscapes, human influences tend to produce abrupt boundaries (Forman and Godron 1986). Yet, traces and patches of primal nature can still be found in the remoter areas, as marginalised remainders, such as the Wadden Zee in the north. But as was already pointed out above, these reclamation activities had adverse consequences, even from a purely anthropocentric viewpoint. Human cultivation was the main cause of the loss of large 
areas in the north and in the south-west to the sea, notably because of subsidence.

From a moral geographic perspective it is important to note that these transitions on the level of water management coincided with a transition on the spiritual or ideological level, namely the Christianisation of the northern and western parts of the Netherlands, that is: of the area beyond what once had been the border of the Roman Empire - the Rhine. After the collapse of the Roman Empire, only a few Christian enclaves survived in the south, notably in the Maastricht region. And when in the early middle ages the Franks were converted to Christianity, the Frisians, who inhabited the lower, Holocene parts of the Netherlands held to their pagan convictions. Shortly before 700 A.D., AngloSaxon missionaries began to arrive, but the conversion of the Frisians would prove a time-consuming process. Saint Boniface was killed by pagans defending their faith in 754 and the conversion of the pagan elite during the eighth century A.D. did not imply that paganism was eradicated completely and immediately. Pagan ideas and attitudes lingered on for quite some time. A certain affinity may be discerned between Christianisation on the one hand and the transition from building terps to building dikes on the other. Christianity entailed a more active stance towards nature. Christians regarded themselves as stewards appointed by God, as co-creators, taking active part in the management and restitution of fallen nature. Monasteries played a prominent role in the medieval transformation of soggy wilderness into a place more pleasing to man and God. They played a large part in reclamation projects, just as they did in forest clearance elsewhere in Europe (Wagret 1968, p. 62). Only monastic orders were able to recruit and organise a sufficient number of 'hands' in those days (Terra et Aqua 2001). Elsewhere in Europe, major marshland reclamations were executed by the abbeys of Fulda (Germany), Saint Rémy (Reims), Saint Panthaleon (Cologne), Saint Armand (Tournai) and Saint Baafs (Ghent), while the Flemish Cistercian monks of Ter doest and Ter Duinen became famous for their hydraulic engineering in the Dutch province of Zeeland. Among the earliest recorded reclamations was that of the Bishop of Bremen who in 1103 had a huge marsh area east of the River Elbe drained and cultivated. And it was in a charter of the cistercian abbey of Middelburg dated 1219 that the word polder first appeared. The great abundance of Dutch villages created during this period with names ending in kerke (church) or-kapelle (chapel) likewise testifies to prominent ecclesiastical activity. Finally, in draining activities by experienced Dutch colonists in the north of Germany, the church played a similar, no less decisive role (Wagret 1968, p. 86). Christianity, as an ideology, rendered the erection of dikes and the reclamation of wetlands morally legitimate, or even obligatory. A demarcation was introduced between the 'baptised' and humanised areas on this side of the dikes, and the diffuse and unreliable realms beyond. The dike materialised a form of moral criticism, directed at previous generations of pagans who, faced with natural phenomena, had been overwhelmed by a mixture of fear and awe. They 


\section{HUB ZWART}

had regarded uncultivated nature as the abode of their gods and had settled for a more passive attitude. Time had come for the demystification of nature.

The diffuse, fluid, ever-changing boundaries between land and water, as they had existed since time immemorial, began to give way to more discrete and permanent demarcations, while pre-Christian awe gave way to aquaphobia, to a long-term policy of building and strengthening dikes. The construction of dikes and ditches, however, was not the end but rather the beginning of a chronic combat. Christian reclaimers began to disturb a natural equilibrium between the elements that had developed over a long period of time. Their activities, directed at draining and reclaiming peat-bog marshes, resulted in a substantial lowering of the surface. The cultivation of the peat-bog wilderness initiated a process that would make the Dutch increasingly dependent on their hydraulic devices. Moreover, during the medieval period the sea level had started to rise again and this combination of anthropogenic and natural factors resulted in a late medieval atmosphere of crisis. A series of dramatic floodings, known as the late-medieval transgressions, created a sea (the Zuyderzee) in the very heart of the country. The element of water literally gained ground. The sea advanced from the north as well as from the south-west, while east of the dune area a series of pools, ponds and marshes gradually formed huge lakes (such as the Haarlemmermeer) that continued to expand. The increasing use of peat for fuel aggravated the situation even more. Gravity-flow drainage was no longer adequate. A still more active, more drastic form of water management became necessary. But this also called for a more active, more aggressive ideology than traditional Christianity had been.

\section{SIMULTANEOUS REFORMATIONS}

The technical device that would make a more active, offensive and large-scale form of water management possible was the windmill. The first known use of a windmill to displace water was recorded in 1408 (Tebrake 1985; Van de Ven 1993). The erection of batteries of windmills for the purpose of draining water proved very effective and allowed the Dutch to build polders of a much larger size during the Dutch classical (or 'Golden') age - the seventeenth century. In order for a polder to be created, lakes, marshes or coastal areas were encircled by a dike and batteries of windmills were constructed to pump the water out. These tools became the typical artefacts, the icons of a new Dutch landscape. Artificial canals, controlled by sluices, transported the water to the sea. Dams and sluices were built to close off sea entries and to control the movements of rivers. But the impoldered areas subsided even more and this made the Dutch even more dependent on their new technologies.

These new forms of water management were accompanied and stimulated by changes in other realms of culture. To begin with, practical expertise began to be 
written down and printed rather than transmitted orally. Practical hydraulic knowledge began to migrate from the unwritten spheres of life to that of published scholarly discourse. During this period, science flourished in the Netherlands. Simon Stevin (1548-1670), for example, was a gifted mathematician who also took an interest in technical (notably hydraulic) problems. His scientific publications hardly deal with technical issues, but his many applications for patents testify to his hydraulic involvement. As early as 1584 he was granted a number of patents by the Dutch authorities on various inventions, most of them having to do with drainage (Struik 1970, p. 5). He worked on mills, sluices and canals and with the help of extensive calculations he was able to improve the windmill, while his son Hendrik (a mathematician in his own right) in 1667 devised a bold plan for the reclamation of the Zuyderzee. From 1588 onwards Simon Stevin, together with Johan Cornets (the father of Hugo) de Groot, built and improved a number of windmills, using a scoop wheel. But the windmill would be subject to further significant improvements during the decades to come. In 1634 Symon Hulsebosch introduced the Archimedes screw, a device that replaced the scoop wheel and by means of which water could be lifted up to four metres. From the late sixteenth century onwards, extensive reclamation projects were realised, such as the draining of the Beemster (16071612), the Purmer (1617-1622), the Wormer (1624-1626) and the Schermer (1631-1635). The drained areas were carefully parcelled out in a strictly geometrical pattern. Whereas Renaissance engineers such as Andries Vierlingh (1570), dikemaster to William the Silent, had opted for 'persuasion' rather than force in dealing with aquatic nature, the new engineers of the classical age displayed a much stauncher attitude (Lambert 1971). One of them was Jan Adriaanszoon, a self-made man, born in De Rijp, a notorious waterland area, who nicknamed himself Leeghwater ('Empty-Water' in English) and claimed to have been involved in all the important reclamation projects of his era (1641, p. 15), although in critical studies it is said that his contributions have been overestimated (Struik 1958). In 1641 he published his Haarlemmermeerboek which contained detailed plans for the reclamation of Harlem Lake, some four metres deep, covering an area of 18,000 hectares of fertile land, threatening agricultural areas as well as major towns (even Amsterdam itself). Leeghwater described it as 'a huge, harmful, pernicious water' and as 'a wolf that eats away land' (1641/1764, p. 7). He had wanted to deploy no less than 160 windmills in order to achieve his goal, but the reclamation of this lake would have to wait until the nineteenth century, when steam engines had replaced the picturesque, emblematic windmills of the classical era.

A no less dramatic transition occurred on the ideological level, namely the rise of protestantism. There is an evident affinity between polderland and Calvinism. In his book on the birth of capitalism and protestant ethics, Max Weber (1965) points out how calvinistic protestants excelled and took pride in maintaining themselves in a hostile natural environment. Nature was fundamen- 


\section{HUB ZWART}

tally distrusted and the Dutch Calvinists put their trust solely in God. Life in threatening surroundings called for a methodical and disciplined way of existence, based on diligence and labour. Traditional Christian constraints on the accumulation of capital were removed and since according to protestant ethics the profits of labour had to be reinvested rather than spent, huge sums became available for financing ambitious and expensive reclamation projects. The classical windmill alone represented an enormous investment in those days. A new type of human being emerged, the protestant self-made man, dwelling in a self-made environment. The natural world, the inhospitable semi-maritime realms of old, were now radically disenchanted and Kreaturvergötterung (deification of nature) was vehemently rejected. The late medieval transgressions, such as the notorious St. Elizabeth's Day Flood (November 18, 1421) that created a huge wetland area called the Biesbosch and the flood of 1570 that created the wetland area of Saeftinghe in Zeeland, were reinterpreted as the Great Deluge of the Dutch nation, a calamity that signified the downfall of a morally deficient, medieval world, a 'winnowing of souls', as Schama (1987, p. 38) calls it. It ended one world, while a new and cleaner world was reborn, sealed by a new covenant with God. Political geography (the emergence of the Netherlands as an independent nation) and environmental geography (land reclamation by means of polders and windmills) were all part of one complex, one Gesamtbild so to speak. The old water-devil, Prince of the Floods, commemorated in many coastal names, had been intimidating previous generations long enough and was now finally driven out, together with the Spanish forces and catholicism. Political borders and geographical demarcations were established simultaneously. The word reclamation itself is not a neutral term, but has evident moral connotations. The protestant reclaimer takes back what is his: the land that had been expropriated from the human sphere during the late medieval period. Nature had to be controlled and disciplined with the help of polders, canals, sluices, dikes, and, above all, with the help of a new ideology.

\section{PHYSIOGNOMIES}

In the previous sections, a series of landscapes has been described in historical succession: the terp-landscape, the dike-landscape, the polder-landscape. But what kind of impression or Totaleindruck (Von Humboldt) did these landscapes evoke? What kind of view or Ansicht did they offer? And what were the typical plant forms, the vegetal icons that awarded them their identity, their face?

Pliny's contemporaries who visited the landscape of the terps were overwhelmed by its desolation, its emptiness, its shapelessness. In the lower, slowly subsiding and periodically flooded areas, sphagnum peat and other forms of marshland vegetation must have been omnipresent, but Roman visitors were most of all struck by the formlessness of this damp and dreary world, by the lack 
of clear distinctions between land and water, and by the absence of discrete and recognisable vegetable forms. This diffuse landscape could hardly be called a land-scape at all, as a substantial part of it was covered by brackish, semistagnant water. Pliny inserted his description of the Netherlands right at the beginning of his book on forest trees. Before turning to genuine forest areas, such as interior Germany, he speaks about countries without trees where the sea sweeps in a flood twice a day 'over a measureless expanse' (p. 389). It was an environment, so to speak, without a face.

The introduction of dikes effected a 'greening' of the Dutch landscape. The bleakness of its semi-stagnant waterlands gradually gave way to a completely different type of surface, dominated by grass forms. Primal nature (oernatuur) gradually gave way to agricultural nature (boerennatuur), where the imprints of human intervention and rectification were omnipresent.

Subsequently, the large-scale reclamation projects of the protestant era once again yielded huge stretches of fertile soil. Notably in areas on the boundaries of dunes and polders, the soil proved favourable for growing bulbs and colourful flowers. Wealthy calvinists were not allowed to spend their money on a grand scale, but there were no moral objections to decorating one's garden. Thus, besides the windmill, the reclamation era (the Dutch 'classical age') also produced the second landscape icon that still gives the Netherlands its face: the bulbous plant, notably the tulip. Tulipmania raged in Holland in the 1630s and reached its peak in 1636-1637. Astonishing amounts were paid for the most bizarre and colourful varieties. It was the first 'hype' in history. And when the government finally intervened to end the trade, many were ruined in what was the first example of a stock-market crash. What is the significance of this episode from the point of view of moral geography?

\section{TULIPMANIA, OR: THE BEAUTIFUL AND THE SUBLIME}

As an artificial, highly cultivated plant, the tulip was perfectly suitable for representing an artificial, highly cultivated landscape. The first tulips were introduced into Holland in 1571 from Turkey, probably by the well-known horticulturist Carolus Clusius, professor of botany, who planted them in the newly established Hortus Bonaticus at Leyden where he started a series of experiments (Lambert 1971). The easily modifiable Dutch soil (a balanced mixture of sand, clay and manure) allowed for the production of new varieties. Horticulture became a fashionable way of spending one's time and money, notably in the gardens of the country manors and residences of the protestant rich. Professional botanists experimented in a systematic manner with colour, size and shape. Catalogues were published and tulip bulbs became the object of financial speculations. In 1623 a single bulb of Semper Augustus (red flames on white) was selling for thousands of florins. The tulip was a flower devoid of 


\section{HUB ZWART}

instrumental value. It was not grown because of its nutritional ingredients, nor put to use in any other manner. Rather, it was grown for its own sake, for aesthetic reasons only. It had, so to speak, intrinsic value. It was simply a feast for the eye and symbolised the Sunday of life.

According to Schama (1987), what was so astonishing about the Dutch tulipmania was 'the apparent incongruousness between the banality of the flower and the extravagance of its treatment' (p. 350). Yet, although a tulip may seem humble to $u s$, in those days it was an exotic, distinguished and alluring novelty. Initially the growing of tulips had been a leisure time occupation of the elite, but around the beginning of the 1630s a popularisation of the tulip set in. A new generation of horticulturists entered the scene who started to produce a series of bizarre and expensive specimens. A national, no longer class-linked cliché was invented.

Alexander Dumas, who visited the Netherlands in 1848, published his novel The Black Tulip in 1850. It is set against the backdrop of land reclamation and horticulture in a landscape of windmills and canals. Its main character, Cornelius van Baerle, is a fancier, a connoisseur, solely obsessed by tulips. The wealthy Van Baerle, being at a loss what to do with his time and with his money, becomes engaged in a practice both elegant and expensive. He looks after his tulips with the utmost care and patience, in a methodical and systematic manner, in a scientific manner, keeping exact records and creating the most perfect conditions for his bulbs in terms of temperature, sunshine, soil and wind and thus producing new varieties. He invests all his intellectual and financial resources in growing bulbs. One day, the Horticultural Society of Haarlem offers a prize of a hundred thousand guilders for the production of a black tulip. By means of careful and minute manipulations, Van Baerle succeeds in this laborious task. An envious neighbour, however, likewise a tulip-fancier, tries to ruin him. But while in prison, the jailer's daughter comes to Van Baerle's aid and, by closely following his instructions, she manages to produce the tulip. In those days, tulip growers really went to elaborate lengths to produce new varieties and to protect their precious artefacts from envious neighbours.

From the point of view of moral geography, the Dutch preoccupation with the tulip, transforming it into a national cliché, is quite understandable. As a highly artificial and modifiable plant form it exemplifies and represents a highly artificial landscape. The windmill (the symbol of intelligence and labour) produced it, the tulip adorned it. Kant's distinction between the 'beautiful' and the 'sublime' may help us to further clarify its meaning. According to Kant $(1764,1799)$, there are two ways in which nature appeals to us. Nature can either be beautiful (schön) or sublime (erhaben). In its formless, overwhelming and 'measureless' immensity, nature, notably maritime nature, is not beautiful, but sublime. Flowers, on the other hand, are beautiful, precisely because of their marked and pleasing form. A crystal is beautiful, a mountain sublime. The aesthetic significance of the sublime was discovered by the poets and scientists 
of the eighteenth century, such as Alexander von Humboldt and Jean-Jacques Rousseau. During his walks along the shores of Lac de Bienne, now a wetland restoration reserve, Rousseau found them wilder and more romantic ('plus sauvages et romantiques') than those of Lake Geneva - thus using the word 'romantic' for the first time (1782/1965, p. 89). During the classical age, however, the romantic appreciation of the sublime, overwhelming aspect of nature was still absent. The diffuse and formless immensities of maritime or semi-maritime nature beyond the dikes were emphatically ignored, but the beauty of delicate forms was valued to the extreme. Dutch painters not only immortalised a highly cultivated landscape, but also the flower that gave it a face. The tulip exemplified the beautiful par excellence. Calvinism did not entail a rejection of nature as such. It did reject the diffuse, unstable, unreliable aspect of nature, but valued nature in its pleasing forms, exemplified by the tulip.

Speaking of the Dutch, Kant noticed that they appreciated order, utility and gracefulness. Hegel, who unlike Kant actually visited The Netherlands, carefully analysed the paintings of the Dutch classical era. In the landscapes of the Dutch masters of the Golden Age, he tells us, we see a flat and low terrain, with a foggy horizon and the sea always nearby. Because of the grey and dreary aspect of their natural environment, the Dutch painters became obsessed with light and colours. In their still-lives, the tulip played a decisive part. They painted, as Hegel puts it, the Sundays of their life, spent in a landscape completely reshaped by the human hand and mind. The explanation for this art form, according to Hegel, is to be found solely in Dutch history. The Dutch produced the soil on which they dwelt themselves - Der Holländer hat sich zum größten Teil den Boden, darauf er wohnt und lebt, selber gemacht (1970, p. 222). That is, the Dutch appreciated and immortalised the products of their own making in their still-lives and their landscape paintings. Of all flowers, the tulip aroused the greatest interest. In the floral paintings of Jacob de Gheyn, Ambrosius Bosschaert, Balthasar van der Ast, Christoffel van den Berghe and many others, the tulip always is the dominant flower (Haak 1984).

\section{GROWING TENSIONS}

The policy of land reclamation continued during the eighteenth and early nineteenth century, and in 1798, under the French occupation, water management in the Netherlands became centralised and professionalised (Bosch 2000). The centralising spirit of enlightened France encouraged co-ordinated management and administration in all spheres of public life. As far as water management was concerned, this was well in time, because the 'Little Ice Age' of the early modern period, with its slightly lowered sea level, had ended. Still, this episode in Dutch (water) history is generally regarded as one of stagnation. The Dutch leisured class preferred income and ease to enterprise and exertion. In rural and 


\section{HUB ZWART}

urban areas, poverty and social malaise increased. Due to extensive peatcuttings, new water areas and interior lakes started to undo what previous generations had achieved. The plans for reclaiming the Haarlemmermeer and the Zuyderzee, put forward by Leeghwater and Hendrik Stevin, were not realised. It is interesting to note that the self-content and relative passivity of this era, compared with the frantic industriousness of the classical age, was expressed by nicknaming it after a plant. In 1841 the Dutch poet E.J. Potgieter published a story whose main character Jan Salie ('John Sage') exemplified the general loss of elan. Tulips no longer expressed the Dutch morale and were replaced by this humble plant form, appreciated for its instrumental (herbal) rather than for its intrinsic value.

That the clash between aquatic nature and human culture in fact continued, is emphasised by another literary document of the nineteenth century, namely Theodor Storm's novel Der Schimmelreiter (The Grey Rider), written in 1888, but describing an event that took place in the middle of the eighteenth century. The novel's setting is the coastal zone of the eastern (that is: German) part of Friesland. A huge dike divided the human world from a dark, grey, cold, coastal immensity, the realm of strange apparitions and frightening birds: the Wadden Zee. It is the story of a talented Dike Master who, as a boy, came across a Dutch translation of Euclid's Elements - a clear reference to the significance of mathematics in early modern Dutch water management. He further expanded his autodidactic knowledge by means of clay models and as an adult he tried to apply his rationalistic and methodical approach to improving the art of dike management, but he met with obstinate resistance from his superstitious, less-enlightened environment. The novel describes the clash between, on the one hand, the demonic immensities of the Wadden Zee, forever defying human control and, on the other hand, the mathematical tools and calculative efforts human beings may rely on to warrant their safety. At the same time, on the ideological level, it describes the clash between a Christian, enlightened world, on the safe side of the dike, and an older world filled with pagan, Wotanesque reminiscences beyond it.

The rationalistic, calculative approach, however, made further progress. In 1852 the Haarlemmermeer was finally drained with the help of steam engines (in the twentieth century Schiphol Airport would be built there). Tidal inlets were closed by dikes and other projects, such as the draining in 1874 of the Prince Alexander Polder (6,6 metres below sea-level) followed. But the Zuyderzee still offered resistance. In 1859 the island of Schokland had to be abandoned. It can still be seen today: a small island with a lighthouse and a harbour in the middle of a polder landscape. Yet, in 1891, Cornelis Lely presented his plans for turning the Zuyderzee into a lake. Work did not begin until 1919, but in 1932 the dike that changed the Zuyderzee into the man-made 'Ijssel Lake', separating it from the Wadden Zee in the north, was closed. Polders were created and mud became soil, while brackish and saline water was gradually replaced by fresh water. 
Common reed, phragmites vulgaris, was sown from helicopters, later to be replaced by grass. What once had been bleak and diffuse, became distinct and discrete. Primal nature (oernatuur) was converted into agricultural nature (boerennatuur). New settlements received the names of old ones that had long ago been surrendered to the sea. This ambitious and successful project again expressed a sense of moral criticism, directed towards the older generations of the John Sage era.

When Sigmund Freud visited the Netherlands in 1920 he was deeply impressed by what he saw happening there. In a famous passage he compared psychoanalysis to the Trockenlegung (impolderment) of the Zuyderzee (Freud 1932). Where Id was, the Ego should become ('Wo Es war soll Ich werden'). According to Freud, the basic objective of psychoanalysis is to allow the Ego to reclaim (aneignen) parts of the Id. Once again, this metaphor emphasised the synchronicity between changes in water management on the one hand and ideological transitions on the other, between Kulturarbeit on the hydrotechnical and on the psychotechnical level. In Das Unbehagen in der Kultur (Civilisation and its Discontents) Freud had already indicated that 'culture' literally means cultivating the earth, and defending cultivated earth against the forces of nature. Ideally, according to Freud, culture is a landscape in which optimal use is made of resources and space, where rivers are regulated and excess water is drained off by canals (1930, p. 451). Moreover, Freud points out that such a 'polderisation' of nature is often supplemented by the careful treatment of beautiful things, such as flowers on windowsills (p. 452). It is quite clear that in his ideal picture of a cultivated landscape par excellence, Freud is actually thinking of the Dutch landscape that he visited himself. Paul-Laurent Assoun (1987) has emphasised that for Freud the Dutch polder landscape indeed served as an image of culture as such. In fact, Freud visited the Netherlands three times, in 1908, 1910 and 1920. During the first two visits, he went to see the cities, such as The Hague, Delft and Leyden, in whose museums he studied the works of the Dutch painters of the seventeenth century. In 1920, however, he visited the Dutch landscape. This time he saw the polders and the canals with his own eyes, travelling by rowing boats, carriages and on foot. Due to these experiences, the polderisation of Dutch nature (not merely pictoral and historical this time, but real) became a metaphor for culture as such. Indeed, he came to regard Holland as the 'prototype' of culture (Assoun 1987, p. 223).

The great project whose realisation Freud actually witnessed was indeed the polderisation of the Zuyderzee, where dykes and hydraulic technologies were used to reclaim significant amounts of land at the expense of sea. A clear demarcation was introduced between culture and nature, at the latter's expense. Paul-Laurent Assoun stresses the remarkable synchronicity between the history of this astonishing project and that of psychoanalysis itself. In 1891, when Freud (together with Breuer) became involved in the therapeutic efforts that would eventually be published as the Studies in Hysteria (1895), Cornelius Lely 


\section{HUB ZWART}

actually presented his famous plan for the closing of the Zuyderzee. The first polder was finished in 1929, the same year in which Civilisation and its Discontents was written. And in 1932, when the huge dike that closed off Lake Ijssel from the Waddensee was finished, Freud's New Lectures on Psychoanalysis were published. The third lecture contains his famous tribute to the epic of polderisation as a remarkable feat of ethical significance. Indeed, by comparing the creation of polders with the practice of psychoanalyses, the ethical analogy between psychological and geographical cultivation was emphasised. Both efforts had one and the same objective, they represented the internal (individual) and external (collective) side of the will to regulate. The building of dykes and the draining of polders exemplified a process of much broader significance. They constituted a work of culture. There was a clear affinity between the 'gospel' of psychoanalysis and modern water policies (Assoun 1987, p. 232).

From the point of view of moral geography the objectives of psychoanalysis and these modern water policies are clearly congenial. Freud visited the Netherlands at a time when the Trockenlegung of primal coastal nature was almost brought to a completion, but he explicitly pointed out that the process of demarcation between Ego and the Id would never be brought to completion. This applied to moral geography as well. Diffuse remainders, such as the Wadden Zee, a bleak and more or less 'primal' zone beyond the new dike, was allowed to remain what it had been since time immemorial - a tidal area more or less untouched by Kulturarbeit. This does not imply of course that the Wadden Zee is 'natural' or 'primal' in an absolute sense. Landscapes and seascapes cannot be categorised as either artificial or wild, but vary along a continuum (Cole-King 1994). Even the Wadden Zee and other leftovers are, in their present form, the result of human choices, policies and modifications.

\section{AQUAPHOBIA AND BIOPHILIA IN COMPETITION}

In the twentieth century, the agenda of Dutch water management was dominated by two large-scale projects: the Zuyderzee project and the Delta Works. The decisions to carry them out were made almost unanimously (Van de Ven 1993, p. 237). Around the turn of the century, when Lely's plan was under consideration, science in the Netherlands experienced its 'second Golden Age' and the famous physicist Lorentz, a Nobel Prize winner, was asked to predict the tidal effects caused by the closure of the Zuyderzee (Bijker 1995). The extensive calculations this involved would take him eight years (Wagret 1960/1968). From the engineer's point of view, the project was an astonishing success. Through the partial reclamation of the Zuyderzee, 166,000 hectares of new land was gained.

But this is only one side of the story. Around 1880, a small but influential group of poets, painters and naturalists began to appreciate the charms and beauties of what was still left of the ancient bogs, swamps, dunes and marches. 
Anton Mauve's sublime painting The Marsh (1885) may stand as a telling example of this new awareness. The movement not only produced an impressive series of paintings, literary works and educational booklets on nature, but scored its first major political success when Jac. P. Thijsse, a primary school teacher and ecologist avant la lettre, together with Eli Heimans and others, managed to arrest the plans, put forward by the city council of Amsterdam, to turn the nearby Naardermeer (Lake Naarden) into a refuse dump. It had been enpoldered three centuries earlier, but was deliberately inundated again shortly after that (in 1629) as a defensive measure to halt the advancing Spanish forces. In 1906, this wetland area became the first official Dutch Nature Monument, a model for the future. The plea for the conservation and rehabilitation of wetland nature, at the expense of both urban expansion and rural cultivation, was an expression of moral criticism directed towards the mastery ethos of the modern engineering mentality. It became a very successful pursuit. The Vereniging tot Behoud van Natuurmonumenten in Nederland [Dutch Association for Nature Conservation], established by Thijsse and Heimans in 1905, now owns over 80,000 hectares of natural areas.

During the 1950s and 1960s, however, aquaphobia definitely reigned. The Delta Works addressed the fact that the province of Zeeland, situated in the south-west of the country, where Scheldt, Meuse and Rhine enter the North Sea, was dangerously exposed to uncontrollable, maritime nature. In the night of February 1, 1953, a major flood claimed 1835 human victims (besides 200.000 farm animals) and inundated 165,000 hectares of arable land. A Delta Commission was established and its members quickly decided to close all sea entries. The Delta Act was passed in 1958. The Delta Works were to reduce the chances of a future flood disaster to virtually zero. Other, more or less similar projects were executed as well. In 1969, for example, a unique ecosystem called Lauwers Zee was closed by a concrete dike, some thirteen kilometres long. Gradually, however, the dramatic ecological consequences of the hydrotechnical agenda became more clear. The public image of the engineer began to change. For decades he had been a hero of safety, but now he suddenly became something of an ecological threat. The Delta Plan implied that unique and complicated ecosystems would be destroyed as tidal activity and the regular inflow of saline water (as well as marine organisms) would come to a halt (Nienhuis and Smaal 1994). One by one, they were to be transformed into stagnant lakes, most of them filled with polluted river water. Initially, the ecological aspects did not receive much attention, as water policies were primarily directed towards the final realisation of the old aquaphobic dream of establishing a permanent demarcation between land and water, fresh and saline water, tidal and non-tidal systems. Hydrotechnical policies had but one unequivocal objective, namely safety, and initially met with unanimous support. During the 1960s and early 1970s, however, the environmentalist movement made the public more aware of the need to protect these unique tidal habitats. Ecology became an issue and the 


\section{HUB ZWART}

ecosystems involved began to be closely monitored. A considerable number of corrections drastically changed the original Delta Plan. Notably, in 1974, the Dutch government decided to change their plans for the most ambitious of all projects, the Easter Scheldt Dam. The original design was replaced by a complex and hydrotechnologically unique compromise: a storm surge barrier that allowed tidal movements to enter the estuary freely, but guaranteed safety whenever a stormflood threatened the area. This massive concrete construction became a new landscape icon, a materialisation of moral criticism directed towards the values and decisions of previous generations. It became a model project, as similar plans, costly but eco-friendly, were developed for other parts of the Delta area. One by one the stagnant lakes are now again transformed into tidal, dynamic systems. The Veerse Meer for example was closed by two dams in 1960 and 1961, and water quality rapidly decreased, notably because of eutrophication. But at this very moment, a twenty million Euro plan has been accepted to revitalise the system by creating a connection with the tidal Easter Scheldt.

Towards the end of the millennium, a reliable frontier of dikes, dunes and dams extended from the Swin inlet in the south-west of the Netherlands to the Dollard in the north-east, fencing off immense areas of reclaimed land, with the lowest point (Alexander Polder near Rotterdam) being 21 feet below sea-level. Natural defences (beaches and dunes) existed side by side with high hydrotechnology. Rivers travelled down constricted beds and man-made channels. Only in marginal areas, patches of wetland and coastal leftovers could still be seen. In the Wadden Zee, small islands and sandbanks were still allowed to disappear and to resurge, and coastlines were still allowed to migrate. Even 'natural' landscape fragments such as dunes and wetlands, however, depended on human interventions and modifications for their survival.

Precisely at this point in history, however, a dramatic reversal has set in. Instead of planning even higher and safer dams and dikes, a new generation of engineers is aware of the need to preserve wetlands, to make room for water and even to breach some of the dikes (Sellers 2001). Instead of regarding water as an adversary, the new engineers agree that wetland areas have to be restored, not for ecological reasons only, but also because they can absorb huge quantities of excess water in times of crisis. What is happening?

\section{DOWN WITH THE DIKES!}

From the Middle Ages until the middle of the twentieth century, the Dutch have worked to replace the diffuse, natural wetlands that still existed during the early medieval period by a highly compartmentalised geography. Now, all of a sudden, the Wadden Zee and other wetland and coastal areas have become issues of public interest, not because new reclamation projects are being planned, but 
rather because a strong plea is made in favour of their conservation or rehabilitation. Dramatic events such as the death of 14,000 seals in coastal waters in 1988 added to environmental awareness. The beautiful, picturesque, agricultural landscape that had gradually been created in the course of history, with its farms, green meadows, canals and dikes, its colourful flowers and grass form vegetations, is challenged by a significant change on the level of aesthetic appreciation: a rehabilitation of the diffuse, desolate nature as idealised by Mauve and others. Not only have the ecological drawbacks of hydrotechnical policies become apparent, even nature itself seemed to protest when in the mid 1990s the huge rivers that transect the Netherlands suddenly started to flood their banks again, as if they refused to accept their straightjackets any longer. A policy was initiated to create natural buffer zones alongside the river beds, as they had existed before the onset of intensive human intervention, that could temporarily absorb the surplus of water during the wet season.

In fact, it all started with an accident. When the last of the polders that had been created in the former Zuyderzee was drained, a marshy landscape began to evolve in the lowest area, earmarked for industry. Before the planned industrial park could be build, planners were faced with something unexpected: nature (Lander 2001). The area involved, called the Oostvaardersplassen, soon developed into a perfect habitat for plant forms and birds associated with a more natural landscape. But instead of correcting their negligence, the planners made a remarkable decision. The Oostvaardersplassen were to be given back to nature. They were to be recognised officially as a natural reserve and as a model for future restoration projects (Vera 2000, Wigbels 2000).

This was the beginning of a significant change in the Dutch attitude towards water management. It manifested itself in a series of plans for introducing and developing 'new nature', notably in coastal and wetland areas, and culminated in a series of important documents, like the Dutch Nature Policy Plan (LNV 1990), that not only aims at nature conservation and development, but also at establishing an ecological network by connecting fragmented core areas and new reserves by means of corridors. Freud's famous dictum seems to be reversed: Wo Ich war soll Es werden. Rivers are allowed more space, polders are inundated and at certain places even the sea is allowed in again. In 1997, a nick or groove (kerf in Dutch) was made in a dune area near the town of Schoorl, called the ParnassiaValley, in order to allow a more natural, more dynamic coastal landscape to develop, where wind and water reign. The sea enters the tidal inlet five to ten times a year, so that drifting, calcareous sands may change the properties of the soil, allowing unique forms of vegetation, typical for dynamic dune systems, to reappear and flourish. The ecological value of these border-line ecosystems is now emphatically recognised and it is perhaps a telling coincidence that the valley where the Kerf is situated is named after the Parnassia flower (Parnassia palustris, Grass of Parnassus), 'one of our most beautiful wild flowers', according to the famous Dutch ecologist Victor Westhoff (1970, p. 301). It is a 


\section{HUB ZWART}

pioneer species found in wet dune valleys and flourishing in this type of soil. By creating a dynamic dune landscape, the conditions are realised that will allow this and other precious flowers to return. As sphagnum peat did for the ancient and early medieval period, and tulips for the classical age, the parnassia now functions as a symbol of a particular type of landscape, more natural and diffuse, more dynamic than the modern, compartmentalised and stabilised one: the Parnassia as the counter-tulip, so to speak. Aquaphobia gave way to 'biophilia', not as a genetically based human propensity to affiliate with nature (Kellert anf Wilson 1993; Kahn 1999), but rather as a recent chapter in the history of the way we interact with our environment.

And this is not a temporary craze. Rather, these developments convey a sense of moral criticism directed towards previous generations, less susceptible to the values of dynamic coastal and wetland nature. The dream of former generations, namely a completely sealed off and standardised landscape, has become the horror image of the present. Still, the precondition for appreciating new nature is a sense of safety and thus, the engineers of the past have made the present predilection for a more natural landscape possible. The Dutch landscape of the future will be a hybrid landscape, a combination of diffuse, dynamic nature (oernatuur) on the one hand and urban expansion at the other, at the expense of agricultural nature (boerennatuur). There will, however, be loci of conflict. The Naardermeer, for example, is under pressure once again because of plans to alleviate Amsterdam's pressing traffic problems by building a new highway right beside it.

A new chapter in the history of water management is being written in the Netherlands. Freud's famous dictum - Where Id (bogs, fens and other swampy places) was, ego (arable land) should become - is reversed and aquaphobia gives way to biophilia. Patches of arable land are transformed into wetlands, mud-flats and salt-marshes. The focus is on the rehabilitation of coastal and wetland nature. The Parnassia and similar plant express and symbolise these new values. But what does nature under these circumstances mean and what precisely is the function of 'target species' like Grass of Parnassus?

\section{NEW NATURE AND TARGET SPECIES}

The objective of creating 'new nature' is a difficult and, above all, a paradoxical one. After centuries of intensive cultivation, the original vegetation of the Netherlands has been almost completely destroyed (Arts 1990). The characteristic continuum between fens and bogs, for example, has now almost entirely vanished (Lamers 2001, p. 75). Due to processes like desiccation, habitat fragmentation, pollution, eutrophication, alkanisation and acidification, the biochemical and ecological conditions indispensable for the development of 
natural wetland ecosystems have been irreversibly affected. This excludes the possibility of restoring the natural situation to a truly 'pristine' state. Rather, 'semi-natural states' are regarded as the reference situation for wetland restoration (Brouwer 2001). Furthermore, restoration is only possible within a strict hydrological and biochemical framework. New nature, in other words, will be the outcome of drastic and scientifically informed human interventions. Careful experiments are conducted to monitor restoration efforts as closely as possible. By modifying the biochemical and hydrological conditions, it is hoped that the desired semi-natural ecosystems will recover. Certain plant species play a significant role in this process. They function as target species or bio-indicators. The incidence of certain plant forms (like the Grass of Parnassus for example) is regarded as a standard by means of which the effectiveness of restoration policies can be measured. To assign the role of bioindicator to a particular species is, of course, a human decision, and a matter of conflict at times. Monotonous reed stands or Salix shrubs, for example, can be very valuable for the restoration of certain bird populations, but are not regarded as such from a vegetation perspective (Lamers 2001, p. 87).

From a philosophical perspective, the production of new nature is structured more or less like an experimental design. Biochemical and hydrological conditions are established and varied by scientists (or scientifically informed managers) with the purpose of causing certain ecological effects, or testing the effectiveness of certain strategies. The conditions are defined in chemical terms, that is: in terms of key elements like $\mathrm{C}, \mathrm{S}, \mathrm{N}$ and $\mathrm{P}$ and in terms of concentrations of $\mathrm{NO}_{3}{ }_{3}^{-}, \mathrm{SO}_{4}{ }^{2-}, \mathrm{PO}_{4}{ }^{3-}$, etc. By modifying the chemical composition of the water, and by maintaining a strict water level regime, certain target species, acting as bio-indicators, are 'invited', so to speak, to take possession of their reconstructed, semi-natural habitats. New nature is, in other words, a dialogue between the scientist (who modifies the conditions in a systematic and wellconsidered manner) and nature, acting as natura naturans, bringing forth the desired plant forms (the natura naturata), not completely of its own accord, but in response to human intervention. Scientists (ecologists, biochemists, and others) try to create the favourable conditions in order to allow nature to manifest itself in the form of favoured species. Nature is regarded as a collaborating and enhancing factor in the process of landscape development. But what precisely is the philosophical 'physiognomy' of this landscape, and of the target species that give it a face? We may answer this question by focussing on the role the sciences have come to play.

Pliny practised a particular branch of science called natural history: the systematic collection, classification and interpretation of natural data, and so did Alexander von Humboldt. They adopted a passive rather than an active stance towards nature insofar as they were observers of nature rather than experimentalists. The performance of an experimental trial always involves an 


\section{HUB ZWART}

element of manipulation, of intervention. Pliny, moreover, described the impression made by the Dutch landscape as such, the Totaleindruck so to speak, rather than the discrete plant forms it contained.

During the early modern period, however, horticulture became an experimental science, practised by scientists like Clusius who allowed their practical knowledge to migrate from verbal forms of transmission into written discourse, thus stepping forward as concrete individuals whose achievements were recorded in the annals of history. These horticulturalists focussed their attention on 'plastic' plant forms that could be easily modified. The tulip became an experimental, but also an aesthetic flower, valued not for its instrumental but rather for its intrinsic worth, as we have seen. As such, it entered the sphere of human investment and exchange. The tulip as an experimental species, as an object of scientific interest and horticultural manipulation, was soon overshadowed by the tulip as a commodity and an object of art.

In the twentieth century, however, the scientific and experimental aspect of plant forms became increasingly important. Around 1900, during the 'Second Golden Age', the experimental botanist Hugo de Vries elected the Evening Primrose (Oenothera Lamarckiana), which grew in masses in meadows in the neighbourhood of Amsterdam, as his model species. He observed how existing varieties disintegrated spontaneously into a number of new forms and concluded that evolution proceeds by distinct changes which he called 'mutations'. Thus, the Evening Primrose soon became an experimental flower par excellence. Its experimental employability overshadowed its aesthetic qualities. It stimulated a new scientific practice that would eventually produce extremely powerful tools for manipulation.

What about the model species of the present? They are experimental species in the sense that they serve as bio-indicators in an experimental setting. Although the Grass of Parnassus (and other plant forms associated with semi-natural landscapes) have been valued for aesthetic reasons as well, notably by authors like Thijsse and Westhoff, who were still observers of nature rather than experimentalists, they now basically function as units in a series of experiments in which the scientists determine the (biochemical) conditions (the $\mathrm{X}$-axis so to speak) that will allow nature to express itself in a certain manner (indicated on the Y-axis). Whereas painters like Van Gogh or Mauve tried to convey a Totaleindruck of landscapes they depicted, ecologists and other scientists reduce the landscape to measurable variables when they monitor ecosystems by chemically analysing water samples or by counting plants or birds, in order to process these data with the help of statistical models. In other words, the scientists have left their laboratories (as in the Van Gogh era painters had left their studios) and regard the semi-natural landscape as a laboratory. New nature is, literally as well as metaphorically, a - fascinating - experiment. 


\section{AQUAPHOBIA, TULIPMANIA, BIOPHILIA}

\section{REFERENCES}

Arts, G. 1990. Deterioration of Atlantic softwater systems and their flora: a historical account (Thesis). Nijmegen: University of Nijmegen.

Assoun, P.-L. 1987. 'Freud et la Hollande'. In: H. Stroeken, En analyse avec Freud. Paris: Bayot, pp. 203-5.

Bijker, W. 1995. 'Sociohistorical technology studies'. In S. Jasanoff et al (eds) Handbook of Science and Technology Studies, pp. 229-56. Thousand Oaks: Sage.

Bosch, T. 2000. Om de macht over het water. De nationale waterstaatdienst tussen staat en samenleving 1798-1849.

Breuer, J. and S. Freud 1895. 'Studien über Hysterie'. In: S. Freud, Gesammelte Werke 1. London: Imago, 1940. [Studies in Hysteria. Trans. A.A. Brill. Boston: Beacon: 1950]

Brouwer, E. 2001. Restoration of Atlantic softwater lakes and perspectives for characteristic macrophytes. (Thesis). Nijmegen: KUN.

Cole-King, A. 1994. 'Coastal and marine conservation in Britain: ecology and aesthetics, land and sea'. Environmental Values 3: 139-53.

Dumas, A. 1850 [1993]. The Black Tulip (ed. D. Coward). Oxford: Oxford University Press.

Forman, R. and M. Godron 1986. Landscape Ecology. New York: Wiley.

Freud, S. 1930. 'Das Unbehagen in der Kultur'. Gesammelte Werke XIV, pp. 421-507. [Civilisation and its Discontents. Transl. J. Strachey. New York: Norton, 1962]

Freud, S. 1932. 'Die Zerlegung der psychischen Persönlichkeit'. In Neue Folge der Vorlesungen in die Psychoanalyse. Gesammelte Werke XV [New introductory lectures on psycho-analysis. Translation by W.J.H. Sprott]. New York..

Haak, B. 1984 [1996]. The Golden Age. Dutch Painters of the Seventeenth Century. New York: Stewart, Tabori and Chang.

Hegel, G.W.F 1970. Vorlesungen über die Ästhetik 1. Werke XIII. Frankfurt am Main: Suhrkamp.

von Humboldt, A. 1808 [1975]. Ansichten der Natur. Stuttgart/Tübingen. [Views of Nature. New York: Arno Press, 1975].

Information and Documentation Centre for the Geography of the Netherlands (IDG). IDG-Bulletin 1996.

Kant, I. 1764 [1960]. 'Beobachtungen über das Gefühl des Schönen und Erhabenen'. In Werke in 6 Bänden 1: Vorkritische Schriften. Köln: Könemann, pp. 191-256. ['Observations on the feeling of the beautiful and sublime', trans. John T. Goldthwait. Berkeley: 1960].

Kant, I. 1799 [1924/1952]. Kritik der Urteilskraft (Hrsg. K. Vorländer). Hamburg: Meiner. [The Critique of Judgement, trans. J. Meredith. Oxford: Clarendon Press, 1952].

Kahn, P.H. 1999. The Human Relationship with Nature: Development and Culture. Cambridge: MIT Press.

Kellert, S.R. and E.O. Wilson (eds) 1993. The Biophilia Hypothesis. Washington D.C.: Island Press.

Lambert, A. 1971. The Making of the Dutch Landscape: A Historical Geography of the Netherlands. London/New York: Seminar Press. 


\section{HUB ZWART}

Lamers, L. 2001. Tackling biogeochemical questions in peatlands (Thesis). Nijmegen: KUN.

Lander, B. 2002. Building Wilderness: New Nature in the Netherlands (in press). http:/ /www-filosofie.sci.kun.nl/ci/e-journal/vol1/ea11.html

Leeghwater, J.A. 1641 [1724]. Haarlemmermeerboek [The Haarlemmer Lake Book]. Amsterdam: Visser/Cornelis.

LNV 1990. Nature Policy Plan of the Netherlands. The Hague: Ministry of Agriculture, Nature Management and Fisheries.

Nienhuis, P. and A. Smaal 1994. 'The Oosterschelde estuary: a case-study of a changing ecosystem'. Hydrobiologia, 282/283, 1-14.

Pliny [1945/1960]. Natural History, Volume IV [transl. H. Rackham]. London: Heinemann / Cambridge: Harvard University Press.

Rousseau, J.-J. 1782 [1965]. Les rêveries du promeneur solitaire. Paris: Grenier.

Schama, S. 1987. The Embarrassment of Riches: An Interpretation of Dutch Culture in the Golden Age. London: Fontana.

Sellers, F. 2001. 'Man versus water: a shift in tactics'. The Washington Post, January 9.

Storm, Th. 1888 [1931]. Der Schimmelreiter [The Grey Rider]. Ed. C. Brouwer, G. Ras. Groningen: Wolters.

Struik, D.J. 1970. Simon Stevin: Science in the Netherlands around 1600. The Hague: Nijhoff.

Struik, D.J. 1958 [1981]. The Land of Stevin and Huygens: A Sketch of Science and Technology in the Dutch Republic during the Golden Century. Dordrecht: Reidel.

Tebrake, W.H. 1985. Medieval Frontier: Culture and Ecology in Rijnland. Texas University Press.

Terra et Aqua 2001. International Journal on Public Works, Ports and Waterways Developments [http://www.iadc-dredging.com/terra-et-aqua/1999/77-4.htm]

van de Ven, G.P. (ed.) Man-made Lowlands: History of Water Management and Land Reclamation in the Netherlands. Utrecht: Matrijs.

Vera, F. 2000. 'Giving the land back to nature: Nature development in the Netherlands'. In The Low Countries: Arts and Society in Flanders and the Netherlads, 1999-2000. The Flemeisch-Netherlands Foundation.

Vierlingh, A. 1570 [1920]. Tractaet van Dijckagie [A Treatise on Dike Management]. The Hague: Nijhoff.

Wagret, P. 1968. Polderlands, trans. M. Sparks. London: Methuen.

Weber, M. 1965. Die protestantische Ethik (Hrsg. J. Winckelmann). München/Hamburg: Siebenstern [The Protestant Ethic and the Spirit of Capitalism, trans. Talcott Parsons. London: Routledge, 1992].

Westhoff, V. et al 1970. Wilde planten: flora en vegetatie in onze natuurgebieden, Deel 1 [Wild Plants: Flora and Vegetation on our Natural Areas, Part 1]. Deventer: Vereniging tot Behoud van Natuurmonumenten.

Wigbels, V. 2000. Oostvaardersplassen: New Nature below Sea Level. Zwolle: Staatsbosbeheer Flevoland-Overijssel. 